\title{
Addressing Conflict in the Fifth Century: Rome and the Wider Church
}

\author{
Bronwen Neil \\ Macquarie University and University of South Africa \\ bronwen.neil@mq.edu.au
}

\begin{abstract}
In seeking to trace the escalation, avoidance or resolution of conflicts, contemporary social conflict theorists look for incompatible goals, differentials in power, access to social resources, the exercise of control, the expression of dissent, and the strategies employed in responding to disagreements. It is argued here that these concepts are just as applicable to the analysis of historical doctrinal conflicts in Late Antiquity as they are to understanding modern conflicts. In the following, I apply social conflict theory to three conflicts involving the late antique papacy to see what new insights it can proffer. The first is Zosimus's involvement in the dispute over the hierarchy of Gallic bishops at the beginning of the fifth century. The second and longest case-study is Leo I's intervention in the Chalcedonian conflict over the natures of Christ. The final brief study is the disputed election of Symmachus at the end of the fifth century.
\end{abstract}

\section{Keywords}

Christology - Council of Chalcedon - Late antique papacy - Leo I, pope - papal letters - social conflict theory - Symmachus, pope - Zosimus, pope

The term "conflict" is usually read as a negative, especially when used in the same phrase as "religious". However, as sociologist Georg Simmel observed, conflict can also have a powerful impact as a cohesive force for the development of social identity. ${ }^{1}$ Religious conflict, when handled by a bishop of politi-

1 G. Simmel, Soziologie: Untersuchungen über die Formen der Vergesellschaftung, Berlin, 1908, pp. 186-255; L.A. Coser, The Functions of Social Conflict: An Examination of the Concept of Social 
cal acuity, can also serve to strengthen the cohesion of one orthodox Christian social order at the expense of another. Such a bishop was Leo of Rome, who held the see from 440 to 461 during one of the most tumultuous periods in the city of Rome's history. The major doctrinal conflict of his pontificate and indeed of his century concerned the definition of the natures of Christ, and it continues to have repercussions in contemporary relationships of the eastern churches with each other and with the church of Rome. It is thus worthy of further analysis in light of recent developments of the Weberian paradigm in the form of social conflict theory. In seeking to trace the escalation, avoidance or resolution of conflicts, contemporary social conflict theorists look for the underlying structural reasons for social conflict: incompatible goals, differentials in power and access to social resources, the exercise of control, the expression of dissent, and the strategies employed in responding to disagreements. ${ }^{2}$ These concepts, I argue, are just as applicable to the analysis of historical doctrinal conflicts in Late Antiquity as they are to understanding modern conflicts. I compare Leo's successful intervention in the Chalcedonian dispute with two other instances of social conflict in the same century, in the pontificates of Popes Zosimus (417-418) and Symmachus (498-514).

\section{The Relevance of Social Conflict Theory to Doctrinal Conflict in Late Antiquity}

Over the course of the fifth century, the incumbents of the Roman see came to claim a primacy of authority over all other bishops. ${ }^{3}$ This source of conflict with other bishops in the Christian oecumene has been examined theologically

Conflict and its Use in Empirical Sociological Research, New York, 1956, esp. pp. 111-19, on the function of ideology in conflict. I am grateful to the anonymous reviewers for their suggestions for this article's improvement.

2 O.J. Bartos, P. Wehr, Using Conflict Theory, Cambridge, 2002, p. 13, define social conflict as "a situation in which actors use conflict behaviour against each other to attain incompatible goals and/or to express their hostility." This definition is somewhat circular, adducing conflict behaviour as an indication of social conflict.

3 On the earliest claims by Siricius at the end of the previous century, see C. Hornung, "Siricius and the Rise of the Papacy," in: The Bishop of Rome in Late Antiquity, ed. G.D. Dunn, Farnham, 2015, pp. 57-72; A. Ferreiro, "Pope Siricius and Himerius of Tarragona (385): Provincial Papal Intervention in the Fourth Century," in: The Bishop of Rome, ed. Dunn, pp. 73-83. On the claims of Innocent I (402-17), see G.D. Dunn, "Innocent and the Synod of Toledo," in: The Bishop of Rome, ed. Dunn, pp. 89-107. 
and historically, ${ }^{4}$ politically and institutionally, ${ }^{5}$ geo-ecclesiologically, ${ }^{6}$ from the evidence of material culture, ${ }^{7}$ and even economically, as a reflection of "household management" writ large. ${ }^{8}$ While acknowledging the great utility of these approaches, I bring to bear a different methodological approach, combining social conflict theory with close textual analysis of letters and their historical contextualization, to see what new insights it can proffer in relation to a particular conflict, that over the natures of Christ at the Council of Chalcedon (451) and in its aftermath.

Conflict may be broadly defined as "the situation that arises when rival interests can no longer be denied, deflected, negotiated, or contained by the structures and processes ordinarily competent to do so." While religious conflict is that which arises when rival religious interests cannot be resolved in the normal ways, it is important to note that religious conflict may mask other root causes of conflict, whether over politics, material conditions, institutional or social status, or a combination of these factors. Based on the work of German philosopher Max Weber (1864-192), one of the founding fathers of the modern disciple of sociology, Weberian conflict theory has allowed scholars to draw

4 E.g. S. Wessel, Leo the Great and the Spiritual Rebuilding of a Universal Rome (Supplements to vc, 93), Leiden, 2009; B. Green, The Soteriology of Leo the Great (Oxford Classical Monographs), Oxford, 2008; L. Casula, La christologia di san Leone magno: Il fondamento dottrinale e soteriologico (Dissertatio Series Romana, 27), Milan, 2000; C. Anang, The Theology of the Passion of Christ in the Sermons of St Leo the Great, PhD Diss., Pontificia Universitas Gregoriana, Rome, 1999 .

5 G.E. Demacopoulos, "Are All Universalist Politics Local? Pope Gelasius I's International Ambition as a Tonic for Local Humiliation," in: The Bishop of Rome, ed. Dunn, pp. 141-153; M.R. Salzman, "Leo in Rome: The Evolution of Episcopal Authority in the Fifth Century," in: Istituzioni, carismi ed esercizio del potere (IV-VI secolo d.C.), ed. G. Bonamente, R. Lizzi Testa, Bari, 2010, pp. 343-356.

6 This is the phrase coined in two recent studies by P. Blaudeau, Le Siège de Rome et l'Orient (448-536). Étude géo-ecclésiologique (Collection de l'Ecole française de Rome, 460), Rome, 2012; P. Blaudeau, Alexandrie et Constantinople (451-491). De l'histoire à la géo-ecclésiologie (Bibliothèque des écoles françaises d'Athènes et de Rome, 327), Rome, 2006.

7 See especially L. Grig, "Competing Capitals, Competing Representations: Late Antique Cityscapes in Words and Pictures," in: Two Romes. Rome and Constantinople in Late Antiquity, ed. L. Grig, G. Kelly (Oxford Studies in Late Antiquity), Oxford, 2012, pp. 31-52; C. Ribeiro Machado, "De domus a titulus: um aspecto da cristianização da Roma tardo-antiga," Anuario del Centro de Estudios Historicos 'Prof. Carlos S.A. Segreti', 12 (2012), pp. 21-32.

8 K. Sessa, The Formation of Papal Authority in Late Antique Italy: Roman Bishops and the Domestic Sphere, Cambridge, 2012.

9 B. Lincoln, "Conflict," in: Critical Terms for Religious Studies, ed. M.C. Taylor, Chicago, 1998, p. 65 . 
valid conclusions about the structure of authority - charismatic, traditional, and legal - that operates in human society and regulates human interactions. ${ }^{10}$ According to Weber's influential work, Wirtschaft und Gesellschaft. Grundriß der verstehenden Soziologie, first published posthumously in 1922, conflict in human interactions is caused not merely by economic inequity but also by inequality in power and resources. Property, prestige and power were therefore important factors underlying social conflicts. Weber defines church as a "compulsory hierocratic organization" which applies hierocratic coercion to enforce its order by applying or denying religious benefits, and believes its administration has a legitimate monopoly on such psychic coercion. ${ }^{11}$

A more recent development of the Weberian analysis is social conflict theory. The work of Peter Bell, ${ }^{12}$ Pierluigi Piovanelli, ${ }^{13}$ Maijestina Kahlos, ${ }^{14}$ and oth$\mathrm{ers}^{15}$ has shown that ostensibly religious conflicts can mask deeper causes of conflict at the social level. These scholarly insights need to be taken into account alongside more traditional historical and theological perspectives. It is argued here that such deep causes characterised fifth-century conflicts at three levels: within the church of Rome, between Roman bishops and the eastern churches, and between Rome and other western sees. The following three case

M. Weber, Economy and Society: An Outline of Interpretive Sociology, ed., trans. G. Roth, C. Wittich, Berkeley - Los Angeles, 1978, pp. 215-254, on types of domination. Weber, Economy and Society, pp. 53-54.

12 Bell, Social Conflict, pp. 35-45, applies the theoretical framework developed by Emile Durkheim, Karl Marx, and Max Weber to social conflict in sixth-century Byzantium, primarily in Constantinople, Asia Minor, and Syria. One of the three major social conflicts he examines was the post-Chalcedonian struggle between Justinian (527-565) and the antiChalcedonian "miaphysite" heirs of Eutyches over the Theopaschite formula (pp. 16o210).

Piovanelli focused on the binary of heterodoxy/orthodoxy as a social norm that operates in many social spheres, not just religion: P. Piovanelli, "Rewriting: The Path from Apocryphal to Heretical," in: Religious Conflict, ed, Mayer, Neil, pp. 87-108, at p. 93, n. 21.

M. Kahlos, Forbearance and Compulsion: The Rhetoric of Religious Tolerance and Intolerance in Late Antiquity, London, 2009.

15 See e.g. P. Sarris, M. Dal Santo, P. Booth (eds.), An Age of Saints? Power, Conflict, and Dissent in Early Medieval Christianity, Leiden, 2011; P. Booth, "Shades of Blues and Greens in the Chronicle of John Nikiou," ByzZ, 104/2 (2012), pp. 555-602; J. Rüpke (ed.), The Individual in the Religions of the Ancient Mediterranean, Oxford, 2013; W. Mayer, G.D. Dunn (eds.), Christians Shaping Identity from the Roman Empire to Byzantium. Studies Inspired by Pauline Allen (Supplements to vc, 132), Leiden, 2015; M. Salzman, M. Sághy, R. Lizzi-Testa (eds.), Pagans and Christians in Late Antique Rome: Conflict, Competition and Coexistence in the Fourth Century, Cambridge, 2015. 
studies illustrate these three levels of ecclesiastical conflict and their underlying social causes.

\section{Case 1: Pope Zosimus (417-418) and Social Conflict in the Late- Antique Roman Episcopate}

Social conflict approaches are especially applicable to the dynamics of power in the Roman episcopate, as shown in a recent analysis of Pope Zosimus's interactions with the rival bishops of Gallic sees in the early fifth century. Adopting a Weberian approach, Geoffrey Dunn demonstrates that changes in Roman provincial arrangements had an impact on the hierarchy among bishops that Zosimus failed to recognize. ${ }^{16}$ The conflict between Zosimus and the bishops of Gaul escalated quickly because, as Dunn noted, "it was built upon years of tension and division within the Gallic churches." ${ }^{\prime 7}$ By the early fifth century, late-antique Roman bishops, imitating the Roman imperial provincial system, had developed an increasingly hierarchical leadership structure, wherein some bishops had power over others. ${ }^{18}$ At the pinnacle they naturally placed themselves, followed by the bishops of Antioch, Alexandria, and, to a much lesser extent, Jerusalem. ${ }^{19}$ The patriarch of Constantinople held an ambivalent place as "New Rome". Bishops of other western sees proved capable of challenging Roman power, among them those of Gaul, especially the rival sees of Arles and Vienne; ${ }^{20}$ those of northern Italy, especially in the metropolitan see of Altinum, where reformed ex-Pelagian bishops posed a problem in the mid-fifth

16 G.D. Dunn, "Zosimus and the Gallic Churches," in: Religious Conflict from Early Christianity to Early Islam, ed. W. Mayer, B. Neil (Arbeiten zur Kirchengeschichte, 121), Berlin, 2013, pp. 169-185.

17 Dunn, "Zosimus and the Gallic Churches," p. 185.

18 Dunn, "Zosimus and the Gallic Churches," pp. 169-170. For bibliography, see D.M. Gwynn, "Episcopal Leadership," in: The Oxford Handbook of Late Antiquity, ed. S.F. Johnson, Oxford, 2013, pp. 876-915.

19 On the complex relationships between the sees of the pentarchy in the fifth and sixth centuries, see P. Blaudeau, "Rome contre Alexandrie? L'interprétation pontificale de l'enjeu monophysite (de l'émergence de la controverse eutychienne au schisme acacien 448-484)," Adamantius, 12 (2006), pp. 140-216.

20 See R. Van Dam, Leadership and Community in Late Antique Gaul, Berkeley - Los Angeles, 1985; R.W. Mathisen, "The 'Second Council of Arles' and the Spirit of Compilation and Codification in Late Roman Gaul," JECS, 5.4 (1997), pp. 511-554. 
century; ${ }^{21}$ the bishop of Ravenna, the Byzantine exarchate whose bishop was usually in open competition with the bishop of Rome; and bishops of Spain, especially in Avila and Galicia, where the rival Christian sect of Priscillianism was suppressed in the late fourth century but re-emerged in the fifth. Local synodal gatherings preserved internal ecclesiastical unity but the question of the unity of the whole church became increasingly an issue as bishops competed with one another for dominance in spiritual authority and material resources. Deep self-interest also played a part, then as now, with bishops seeking to promote their own diocese at the expense of others.

According to Dunn, it was Zosimus's lack of legal and traditional authority, in combination with his abrasive personality and the desire of the bishops of Arles and Vienne to promote their own sees within the hierarchy, which caused the failure of Zosimus's claims to charismatic authority over the bishops of Gaul. ${ }^{22}$ A social conflict analysis would also point to the particularly rich material resources at the disposal of the bishops of Arles and Vienne, and the ways in which they sought to use the authority of the Roman see to enhance their own local authority. Ultimately, Zosimus's attempts to impose Roman authority on the tendentious relationship between two rival Gallic bishops proved beyond his reach. His threats to call down on them the heavenly power invested in him as bishop of Rome were deemed empty and futile. The church of Gaul had sufficient wealth and power of its own to be able to ignore papal bluster. Let us consider how Pope Leo fared forty years later in his attempt to intervene in what was initially a purely eastern internal dispute, the debate over the definition of the natures of Christ.

\section{Case 2: Leo I's Intervention in the Chalcedonian Conflict}

In this case-study, I apply social conflict theory to a famous site of doctrinal conflict, the "heretical" Robber Synod and its orthodox successor, the Council of Chalcedon. In approaching the events of 449 to 451 and their aftermath up to 460 in a new way, I limit myself to one primary actor, Leo the Great, bishop of Rome (440-61), and one literary genre, his letters. ${ }^{23}$ The letters of Pope Leo

21 B. Neil, "A Crisis of Orthodoxy: Leo I's Fight against the "Deadly Disease" of Heresy," in: Ancient Jewish and Christian Texts as Crisis Management Literature, ed. D.C. Sim, P. Allen (Library of New Testament Studies, 445), London - New York, 2012, pp. 144-158.

22 Dunn, "Zosimus and the Gallic Churches," p. 184.

23 For corroborative evidence of Leo's episcopal interactions, we can turn to his ninetyseven sermons: A. Chavasse (ed.), Sancti Leonis Magni Romani pontificis tractatus septem 
afford an excellent illustration of the unfolding of a religious controversy with political underpinnings, from the synod convened at Ephesus in 449 to the Council of Chalcedon in 451, and its development into a social conflict thereafter. The original issue under debate at both councils was how to define the natures and persons of Christ. Leo had a major input to both councils in absentia through the many letters he wrote from 448 to 451 . The most important of these was his lengthy letter to Flavian, patriarch of Constantinople. In other, lesser-known, letters Leo sought to mitigate the disastrous consequences in the East of the acceptance of his Tome to Flavian at Chalcedon. ${ }^{24}$

At work in Leo's attempts to escalate, and then to resolve, the Christological conflict, was the collegiality between bishops (both those to whom he wrote, and those who assembled annually in the Roman synod), which affected his attempts to impose the three kinds of authority identified by Weber: charismatic or spiritual authority, dependent on the incumbent's personal appeal and on his being recognised as the heir of the Apostle Peter; his legal authority as lawmaker for that church; ${ }^{25}$ and the traditional authority held by the leader of the Italian college of bishops and head of the Roman church. We will see below how the college of bishops, led by Leo, acted to limit the monocracy of Emperor Theodosius II, which only increased the monocratic character of Leo's papacy.

From Leo's wide network of epistolary correspondents, it seems that he was a person of considerable influence, in both ecclesiastical and imperial circles. Ep. 124, as well as his Second Tome to Emperor Leo, ${ }^{26}$ may be more accurately described as "treatises" delivering doctrinal guidance, and were designed for

et nonaginta (CCSL, 138/138A), Turnhout, 1973, vol. 2, p. 449. Research on Leo's sermons has generally been piecemeal, apart from the magisterial study of Green, The Soteriology, who considered the sermons as they were preached, as part of the Roman liturgical cycle. Other studies have concentrated on specific themes or feasts, e.g. the Easter homilies in C. Anang, The Theology of the Passion of Christ in the Sermons of St Leo the Great; or the Pentecost and Ascension homilies in Neil, "The Resurrection of the Body." See further B. Neil, "Leo Magnus," in: Latin Preaching in the Patristic Era: Sermons, Preachers, Audiences (New History of the Sermon), ed. S. Boodts, G. Partoens, J. Leemans, Leiden-Boston, 2018, pp. 327-346.

24 Leo, ep. 124, ep. 165, and ep. 170.

25 On the efforts of a slightly later bishop of Rome, Gelasius (492-96), to extend his legal authority beyond the see of Rome through the circulation of his letters, or parts thereof, as decretals, see B. Neil, "Gelasius' Theory of Law at the End of the Fifth Century," in: Shifting Frontiers XII: Transformation in the Fifth Century, ed. N. Lenski, J.W. van Drijvers, Bari, forthcoming.

26 Leo, ep. 165. 
public consumption, not just that of their ostensible addressees. As is usually the case with doctrinal sources from Late Antiquity, the surviving evidence is heavily slanted towards the orthodox (anti-Eutychian, anti-Nestorian) "winners". Leo's exchange of letters from before and after the Council of Chalcedon show both the success with which a bishop could use letters to influence the course of a doctrinal controversy, and the limitations of the medium and its practical constraints. A study of the vocabulary used in Leo's sermons and letters has shown that he was not a great innovator in theological language. ${ }^{27}$ Rather, he drew heavily on the Latin terminology developed by Hilary of Poitiers, Ambrose, Jerome, and Augustine. By citing established precedents from the Latin tradition, he lent weight to his own arguments against Nestorianism and Eutychianism. This was a key strategy in Leo's claim to traditional authority within the universal church, the type of legitimacy based on the sacredness of tradition that Weber called "the oldest and most universal type."28

Leo came to power in an age when violence was a familiar part of Roman life. With the sieges of Rome by the Visigothic forces of Alaric from 408 to 410 within living memory, his pontificate was dogged by the threat of invasion by the Hun leader Attila, who entered northern Italy in the early 450 s and had to be bought off to avert his intended siege of Rome in 452. Leo was part of the delegation that met with Attila in Venetia to negotiate this truce. Not three years later, in May 455, Rome faced invasion by the Vandals, led by Geiseric. Thousands of prisoners were taken from the city, along with much of its portable wealth. ${ }^{29}$ The Vandal occupation of North Africa from 429 had already cut off a crucial food source for the citizens of Rome. The fourteen-day siege by Geiseric and subsequent despoiling of the city left it in desperate straits. As bishop of Rome it fell to Leo to try to restore public order and supply clothing, shelter, food, and water for the people. It is perhaps more explicable in this context that he would take such a hard line against the various sects and schisms that arose in Rome in this period. "Unity of the church" became a slogan for much-needed social cohesion, which Leo sought to achieve by imposing Christian orthodoxy. However, collegiality is, in the words of Weber, "in no sense democratic." ${ }^{30}$ It results rather from privileged groups (in this case

\footnotetext{
27 M.M. Mueller, The Vocabulary of Pope St. Leo the Great (Patristic Studies, 67), Washington DC, 1943, p. 242.

28 Weber, Economy and Society, p. 37. The other two bases of legitimacy are faith, associated with charismatic authority, and enactment, associated with legal authority, the latter being the most common type today.

29 Neil, Leo the Great, 4-11, offers a succinct summary of these events with reference to the primary sources.

$30 \quad$ Weber, Economy and Society, p. 277.
} 
western bishops) trying to protect their privileges by limiting the monocratic tendencies of the leader, the primus inter pares ${ }^{31}$ (Leo, bishop of Rome). The exercise of collegiality in Late Antiquity exceeded Weber's characterisation of it as acting as a limitation on any type of authority. ${ }^{32}$ Instead it was used to bolster one source of authority - that of the bishop of Rome - and to quell the rest, leading to social conflict with adherents of other versions of the Christian faith.

\section{Glaubensparteien}

In our analysis of Leo's attitude towards sectarians and so-called "heretics", we can usefully employ Weber's concept of "parties of faith," (Glaubensparteien). Recent studies of the main "heresies" to impact upon Leo's episcopate - especially Pelagianism, ${ }^{33}$ Priscillianism, ${ }^{34}$ and Manicheism ${ }^{35}$ - can be found elsewhere. I focus here on two Christological positions that were debated and condemned at the Council of Chalcedon in 451: Eutychianism and Nestorianism. We can see the supporters of Eutyches' "one-nature" position, whom Leo called "Eutychians," as embodying two of Weber's parties of resistance to "legitimate types of domination." Weber's doctrinal Glaubensparteien were organised around questions of faith, and arose "out of a disagreement over the content of doctrines or declarations of faith; they take the form of heresies." ${ }^{36}$

31 Weber, Economy and Society, p. 277, gives as an example the Roman Senate before the Gracchi.

Weber, Economy and Society, p. 272: "It is possible for any type of authority to be deprived of its monocratic character by the principle of collegiality."

Lucio Casula, Leone Magno. Il conflitto tra ortodoxia ed eresia nel quinto secolo (Rome, 2002, esp. pp. 102-105; Neil, Leo the Great, pp. 33-35; Wessel, "Leo the Great", pp. 79-85, 97. Wessel, "Leo the Great", pp. 106-114; M. Conti, Priscillian of Avila: The Complete Works (Oxford Early Christian Texts), Oxford, 2009; Neil, Leo the Great, pp. 82-83; H.G. Schipper, J. van Oort (ed., trans.), St Leo the Great. Sermons and Letters against the Manichaeans, Selected Fragments (Corpus Fontium Manichaeorum series Latina, 1), Turnhout, 2000, pp. 2-5.

35 J. van Oort, O. Wermelinger, G. Wurst (eds.), Augustine and Manichaeism in the Latin West, Leiden, 2001; J.K. Coyle, Manichaeism and Its Legacy, Leiden, 2009. On Manicheism in Rome at the time of Leo I, and his letters and sermons on the Manichean threat, see Wessel, "Leo the Great", pp.109-126; Neil, Leo the Great, pp.31-33; Schipper, van Oort, esp. 89-108; B. Neil, "The Resurrection of the Body in Leo the Great's Ascension and Pentecost Homilies", in: Preaching After Easter: Mid-Pentecost Ascension and Pentecost in Late Antiquity, ed. R.W. Bishop, J. Leemans, H. Tamas (Supplements to VC, 136), Leiden, 2016, pp. 373-385; H.G. Schipper, Paus en ketters. Leo de Grote's polemiek tegen de manicheeërs, Heerenveen, 1997.

36 Weber, Economy and Society, p. 286. 
Another type of party of faith, the charismatic, questioned with the charismatic quality of the leader, or created a schism over who was the proper leader. ${ }^{37}$ Both of these party-types describe the supporters of the archimandrite of Constantinople Eutyches, who saw themselves as followers of the true doctrinal authority, Cyril of Alexandria, and therefore as opponents of the patriarch Flavian. ${ }^{38}$

The same two categories of follower, doctrinal and charismatic, characterise supporters of the opposing party, Nestorius, patriarch of Constantinople (428$431)$. When he took up the patriarchal see in 428 , Nestorius was already unpopular with Cyril of Alexandria by virtue of his being the second Syrian to be promoted to the highest see in the East. Nestorius added fuel to the fire by endorsing the preaching of a young priest against the application of the title of "mother of God" (Greek theotokos, literally "the God-bearer") to the Virgin Mary, on the grounds that "Mary was human and it is impossible that God could be born from a human being." ${ }^{39}$ Cyril seized the opportunity and greatly exaggerated the offence of Nestorius, falsely accusing him of Apollinarianism and Pelagianism. In his Book of Heraclides 228, ${ }^{40}$ Nestorius claimed that he could not understand what Cyril meant by the term "hypostatic union" in relation to the incarnate Christ, since Nestorius interpreted hypostasis in the outdated Nicene sense of "real being," the equivalent of essence (ousia). Cyril on the other hand was using hypostasis in the new sense adopted by the Council of Constantinople in 381 to mean "differentiated subject." ${ }^{11}$ Nestorius' theological position on the divinity and humanity of Jesus Christ was informed by the teaching of Theodore of Mopsuestia that there was not a personal union in Christ but "a union of different things in close relation" (henōsis schetikē), a position that came dangerously close to the division of Christ into two hypostases or persons. ${ }^{42}$ The matter was brought to trial at the Council of Ephesus in 431 and Nestorius was convicted and exiled.

Leo I created a false opposition between Nestorians and Eutychians and, by naming whole movements after the thinking of one person, simplified the

\footnotetext{
37 Weber, Economy and Society, p. 285.

38 As posited by G.A. Bevan, P.T.A. Gray, "The Trial of Eutyches: A New Interpretation," ByzZ, 101 (2008), pp. 617-657, Eutychianism was not a genuine heresy but an unswerving adherence to Cyril of Alexandria's formula "one incarnate nature of God the Word."

Socrates of Constantinople, Historia ecclesiastica 7.32 (ed. G.C. Hansen, P. Maraval, Socrates, Histoire ecclésiastique Livre VII [SChr, 506] Paris, 2007, p. 114).

$40 \quad$ F. Nau (ed.), Le livre de Héraclide de Damas, Paris, 1910, p. 138.

41 J. McGuckin, Cyril of Alexandria: The Christological Controversy, Its History, Theology, and Texts, Supplements to vc, 23), Leiden, 1994, pp. 148-149.

42 See McGuckin, pp. 151-174, on associative difference in Christ.
} 
complex doctrinal questions to a simple binary of heresy: Nestorianism or Eutychianism. A difference in theological views that could have generated a complex debate became a social conflict between Christians of neighbouring geographical regions, Egypt and Palestine ("Eutychians") and east Syria (“Nestorians").

\section{"It's in the Post"?}

The monk Eutyches first crops up in Leo's letters in a very favourable light. Eutyches had requested papal support for his attempts to suppress Nestorian resistance to his own views on the incarnation. Leo, unaware of the unorthodox nature of Eutyches' view, praised his concern for this matter, and promised to pursue the elimination of the "heinous poison" of "Nestorianism."43 In December of the same year, Eutyches, by now condemned by Flavian at a council held in Constantinople in November, appealed to Leo for help. ${ }^{44}$ Leo wrote at once to Flavian in some embarrassment and annoyance, asking why he had not been fully informed of the scandal..$^{45}$ Flavian replied that he had indeed informed the pope at the end of $448,{ }^{46}$ but his letter was delayed in transit and crossed paths with Leo's own complaint. Thereupon Flavian sent a second letter to Leo, outlining again Eutyches' double error, which was - he alleged derived from the heresies of the Syrian Apollinaris of Laodicea (that is, Apollinarianism) and the Roman Gnostic Valentine (that is, Gnosticism) ${ }^{47}$ Eutyches' first error was his belief that before the incarnation Christ had two natures, and afterwards only one. His second erroneous doctrine was that the body that Christ took from the Virgin was not of the same nature as a human body. Since it was not of human substance it was not consubstantial with other

43 Leo I, ep. 20, 1 June 448. On the theme of divine impassibility in Leo's Lenten and Christmas homilies, see G.D. Dunn, "Divine Impassibility and Christology in the Christmas Homilies of Leo the Great," ThStud, 62 (2001), pp. 71-85; idem, "Suffering Humanity and Divine Impassibility: The Christology of the Lenten Homilies of Leo the Great," Augustinianum, 41 (2001), pp. 257-271. On the Christological themes of Leo's pascal homilies, see B. Neil, "Leo the Great's Paschal Homilies: A Brief History of Salvation," in: Pascha nostrum Christus. Essays in Honour of Raniero Cantalamessa OFM Cap, ed. P.F. Beatrice, B. Pouderon (Théologie historique, 123), Paris, 2016, pp. 277-290.

44 Leo I, ep. 21.

45 Leo I, $e p .23$.

46 Leo I, ep. 22.

$47 \quad$ Leo I, ep. 26. 
human beings, including the woman who bore him according to the flesh, according to Flavian. ${ }^{48}$

\section{Leo's Tome to Flavian}

In response to Flavian's second letter, Leo promised a full reply.9 This came in the form of the Tome to Flavian, composed on 13 June $449 .{ }^{50}$ The main achievement of the Tome was its succinct formulation of the unique relationship of unity between the two natures of Christ, while avoiding use of the word "one."51 Christ had a human form (by which we understand "nature") and a divine form in such a way that "each form performs what is proper to it in communion with the other, with the Word accomplishing what is proper to the Word, and the flesh fulfilling what is proper to the flesh. ${ }^{52}$ This formula trod the middle ground between the two extremes of "one nature" Christology where the humanity of Christ was dissolved in the hypostatic union (Eutychianism), and the teaching of two distinct persons in Christ, the human and the divine, each with their own nature (Nestorianism). It should be noted, however, that neither Nestorius nor Nestorianism are specifically mentioned in this letter, nor were the terms "Nestorian" and "Nestorianism" ever used by supporters of Nestorius to describe themselves. The same applies to the term "Eutychianism," which Leo I coined as a label for followers of the archimandrite Eutyches. Leo's formula also seemed to be close enough to Cyril of Alexandria's formula "one incarnate nature of God the Word" to satisfy all but the most extreme Cyrillians, the followers of Eutyches in Egypt and Palestine, who were labelled "monophysites" by their detractors. According to Leo's formulation, the natures were joined without Eutychian confusion or mingling on the one hand, and on the other hand without Nestorius's division and separation of the human and the divine.

\footnotetext{
$48 \quad$ Leo I, $e p .20$.

49 Leo, ep. 27.

50 One version of the Tome to Flavian is preserved in the Acts of the Council of Chalcedon: Leo I, ep. 28 (ed. E. Schwartz, Concilium universale Chalcedonense vol. 2: Versiones particulares, part 1: Collectio Novariensis de re Eutychis [ACO, 2], Berlin, 1932, pp. 24-33; trans. Neil, Leo the Great, pp. 96-103. The original Tome was redacted in answer to Flavian's complaint about Eutyches and his heretical activities in Constantinople since 448.

51 Except of course in relation to the single person of Christ, e.g. "joining in one person" (Leo I, ep. 28.3).

$5^{2} \quad$ Leo I, ep. 28.2 .
} 
Leo's assumption of his own legitimacy, on the basis of patristic tradition and its quasi-legal enactment through previous ecumenical councils, is fully evident in this treatise. Similarly, all the bishops who subscribed to the acts of Chalcedon's fourth session referred to his statement in the Tome as being in accord with the statements of faith ratified by the bishops who assembled at Nicaea (325), Constantinople (381), and Ephesus (431). ${ }^{53}$ Some of these signatories also cited its adherence to the standard set by Cyril of Alexandria. An element of coercion cannot be ruled out, since those who disagreed would not have been allowed to add their signatures to the document.

The Tome was to take on a life of its own through its inclusion in the Acts of the Council of Chalcedon. It remained a standard for western and eastern theologians in the Christological controversies of the next two centuries and contributed more than anything else to Leo being assigned the epithet "the Great". However, it was not immune from criticism in the decade following Chalcedon, and Leo found himself having to fine-tune his ideas in a second Christological statement. ${ }^{54}$ Although Leo's authorship of Letter 28 has been frequently questioned, with some scholars attributing it to Prosper of Aquitaine in his role as secretary to Leo from $c .440,{ }^{55}$ we can see its germination in several sermons of Leo, composed between 441 and $445 .{ }^{56}$ Several major western patristic authors exercised an influence, including Augustine, Ambrose, Hilary of Poitiers, and Gaudentius of Brescia. ${ }^{57}$ Originality was not considered a virtue in a dogmatic statement such as this; rather, Leo was concerned to show that his exposition of the relationship between the two natures in the one person of Christ was grounded firmly in tradition, both biblical and patristic. This was the only standpoint from which he could safely condemn Eutyches and Nestorius as heretics. Thus, he appended to Letter 165 a long list of excerpts from various authors to demonstrate that what he was saying had already been said

53 Acts of Chalcedon, Session 4 (trans. Price, Gaddis, pp. 127-146).

54 Leo I, ep. 124.

55 J. Gaidioz, "Saint Prosper d'Aquitaine et le Tome à Flavien," Revue des sciences religieuses, 23 (1949), pp. 270-301; N.W. James, "Leo the Great and Prosper of Aquitaine: A Fifth-century Pope and his Advisor," JTS ns, 44/2 (1993), pp. 554-584; P. Barclift, "The Shifting Tones of Pope Leo the Great's Christological vocabulary," Church History, 66/2 (1997), pp. 221239, at pp. 221-222; S. Pietrini, Religio e ius romanum nell'epistolario di Leone Magno (Materiali per una palingenesi delle costituzioni tardo-imperiali, 6), Milan, 2002, p. 5; M.R. Salzman, "Reconsidering a Relationship: Pope Leo of Rome and Prosper of Aquitaine," in: The Bishop of Rome, ed. Dunn, pp. 109-126.

56 Leo, sermones 21, 22, 23, 24, 51, 54, and 71 (ed. Chavasse, vol. 1, p. cliii).

57 Green, Soteriology, p. 219. 
before, in both Latin and Greek. Such catenae were clear expressions of the bishop of Rome's legitimate claim to traditional authority.

\section{From Theological Rhetoric to Social Violence at the "Robber Synod" of Ephesus (449)}

Around the same time as the arrival of Flavian's second letter to Leo, in May 449, Theodosius II requested Leo's attendance at a council in Ephesus to settle the dispute. Its presider was to be Patriarch Dioscorus of Alexandria, a "Eutychian" and opponent of the patriarch of Constantinople. Refusing the invitation, Leo sent two delegates in his place along with the Tome to Flavian, which was supposed to be read out to the gathering of bishops. Dioscorus, however, escalated the conflict by prohibiting its presentation at the council. Leo was furious at this insult and at the treatment of Flavian, who was deposed as patriarch of Constantinople, and mauled so badly that he died on his way to exile. Leo refused to recognize the Second Council of Ephesus, which had been intended as an ecumenical council of the whole church, denouncing it as "a den of thieves" (Latrocinium). The appellation "the Robber Synod" was quickly adopted by the losing side. The Tome to Flavian had to wait two more years to be heard, when a replacement ecumenical council was convened in October $45^{1}$ by the new emperor Marcian. With Attila on the horizon after his invasion of Gaul, Leo unsuccessfully sought postponement of the council until "a more opportune time." In the end he agreed to send legates, since "present difficulties" did not allow him to travel so far from home. ${ }^{58}$ This time, however, his legates were successful in bringing the Tome to the notice of those present.

Roman views on the primacy of the bishop of Rome prepared the ground for tendentious relations with other sees, especially that of Constantinople. The relationship between the sees of Constantinople and Rome had been fraught since 381 when the bishops present at the Second Ecumenical Council of Constantinople declared that the "new Rome" (Constantinople) should be second only to "senior Rome" in primacy of honour (Canon 3). After the "Robber Synod" of 449, Leo decided to take action against the unorthodox behaviour of Emperor Theodosius II, who had upheld its decisions and refused to reopen the matter. In a diplomatically worded letter (ep. 69), Leo requested that the emperor make a statement of orthodox belief and circulate it among the churches. He also asked that an ecumenical council be held in Italy to resolve the question of so-called "monophysitism" (one-nature Christology). For, Leo

$5^{8} \quad$ Leo I, ep. 89 . 
pointed out, "It will benefit the universal Church as well as your government if, in a single profession of faith by the whole world, there is adherence to belief in one God, one faith, one pledge of human salvation." ${ }^{\prime 59}$ This was a direct challenge to imperial authority, grounded on the superior traditional authority that the bishop of Rome inherited from the apostle Peter, by virtue of his office.

Fate intervened to prevent what would have been a volcanic eruption from Constantinople in response to Leo's polite request. Before Leo's letter arrived, Theodosius met his death in a riding accident while hunting, in mid-450. With Theodosius' death, a new era of rapprochement seemed on the verge of dawning for East and West. The new emperor Marcian and his wife Pulcheria - the sister of Theodosius - were initially very well disposed towards Rome, and its bishop Leo in particular, and wished to uphold his condemnation of Eutyches through the convening of a new council in the East. Imperial institutional authority had intervened to move the conflict onto its next phase.

\section{Intervention in absentia at the Council of Chalcedon (451)}

Although the majority of bishops at Chalcedon supported the Tome, apparently spontaneously asserting Leo's charismatic and traditional authority in their acclamation: "Peter has spoken through Leo!", this should not be mistaken for a unanimous decision. Voices of dissent were silenced by the management and selective recording of the sessions in the Acts, and by the presence of the emperor who presided over the council. In its final session the same council ratified a canon which caused great contention with the bishop of "Old Rome." This was the infamous Canon 28, added to the original twenty-seven canons after a final additional session of the Council, which declared that Constantinople was equal to the Church of Rome, which held "primacy of honour." The basis for New Rome's privileges was the city's status as an imperial capital. The reiteration of this claim at Chalcedon was really an attempt to contain the ambitions of the patriarchate of Alexandria vis à vis Constantinople, by asserting the authority of the emperor over all the churches apart from Rome. In contrast to the deferential tone of Letter 98 in which the bishops assembled at

59 Leo I, ep. 69.2: ... quoniam et universae ecclesiae et vestro hoc imperio profuturum est, si unus Deus, una fides et unum sacramentum salutis humanae, una totius mundi confessione teneatur. (PL 54. 892B; trans. D. Hunt, Letters of Leo the Great (Fathers of the Church, 34), Washington, DC, 1986, p. 140, modified). See also the translation of various letters of Leo preserved in the Acts of the Council of Chalcedon, trans. R. Price, M. Gaddis, 2 vols. (Translated Texts for Historians, 45), Liverpool, 2005. 
Chalcedon sought Leo's ratification of the council's Acts, Canon 28 smacked of imperial hauteur. Leo refused to ratify the Acts while they contained this canon. To stress the see of Rome's superiority to its Alexandrian counterpart, Leo deliberately emphasized the relation of Mark the Evangelist to St Peter as one of disciple to teacher. In 454 Leo sought the support of Proterius of Alexandria, "the successor of St Mark," against Constantinople's "unprincipled ambition," which had "injured the dignity" of the other great sees in the so-called "twentyeighth canon." ${ }^{\prime 0}$ In another letter to Emperor Marcian in 452, he pointed out that the see of Constantinople's claim was not based on any apostolic foundation but on secular power alone. ${ }^{61}$ This appeal to the superiority of his spiritual authority over the traditional authority of the emperor was ultimately persuasive to Marcian, but his imperial successors failed to see Leo's point. The ongoing competition between Old and New Rome was based on much more than doctrinal differences.

\section{After Chalcedon: An Unsatisfactory Resolution}

While the Tome had satisfied some parties, especially the imperial family who were looking for a basis for unity between the opposing factions, many were not satisfied with it or the Council of Chalcedon, including the so-called "monophysite" or "miaphysite" ("one nature") monks in Palestine and Egypt. The dissatisfied parties in Syria eventually set up the rival Jacobite church (now known as the Church of the East) against the imperial Melkites who held to dyophysite ("two nature") orthodoxy. The opponents of the Council of Chalcedon regarded the resolution reached there as a betrayal of both Cyril and Eutyches. Much of their energetic opposition was focussed on discrediting the Tome. In Palestine, and later in Alexandria, the monastic reaction to the Definition of Faith and the canons approved at Chalcedon was violent. When rioting broke out in 453, Leo felt compelled to address a long epistle to those monks who were causing the disturbance. This was Letter $124,{ }^{62}$ composed on the ba-

\footnotetext{
$60 \quad$ Leo, ep. 129 .

$61 \quad$ Leo, ep. 104.3, discussed by P. McShane, La romanitas et le pape Léon le Grand: l'apport culturel des institutions impériales à la formation des structures ecclésiastiques, TournaiMontreal 1979, pp. 160-163.

62 Leo I, ep. 113, c. 15 June 453 (ed. E. Schwartz, Concilium Universale Chalcedonense: Leonis Papae I epistularum collectiones (ACO, 2.4), Berlin-Leipzig, 1932, pp. 159-163, from the latefifth century Collectio Quesnelliana. Trans. Neil, Leo the Great, pp. 106-112).
} 
sis of Homilies 64 and 65, delivered in April of that year. ${ }^{63}$ Leo professed himself outraged to hear that, due to malice or a misreading of his Tome, he himself had been accused of Nestorianism.

In his preface Leo adopted a conciliatory approach, seeking to excuse the monks' scandalous behaviour by attributing it to a misunderstanding caused by a poor Greek translation of the Latin Tome. Leo himself seems to have had limited knowledge of Greek, and the erroneous versions of the Tome that were circulating in the East caused him much concern. We see an unaccustomed touch of real humility when Leo confessed that he was not surprised by the shortcomings of the Greek translations since he, as one of the disputants, could hardly explain such theological subtleties in Latin, his mother tongue. ${ }^{64}$

As in Letter 28, Leo appealed to traditional authority, insisting that his Christological statement was in line with "ancient teaching," and that he also rejected the Nestorian heresy, which the Palestinian monks abhorred. His condemnation of Nestorius is explicit in this letter, unlike in Letter 28. In a significant departure from the Tome he reverts to his original, pre-449, terminology of "substances" in Christ rather than "natures," since talk of two natures in Christ seemed to have Nestorian resonances for the Palestinian monks, being read as implying two persons in Christ. ${ }^{65}$ Letter 124 was later reworked as Letter 165 to Emperor Leo, usually known as the "Second Tome," in which the "nature" terminology was reinstated. ${ }^{66}$ This letter was to have a major impact on the eastern imperial approach to the controversy. Two other developments in Leo's thinking and terminology after the composition of the Tome are worth mentioning in relation to Letter 124: first, his adoption of the Antiochene formula of "the human being having been taken up" (homo assumptus), and second, his distinction between the terms "human being" (homo) for the specific reality of Jesus as a concrete human being, and the adjective "human" (humanus) for the abstract concept of humanity or human nature. ${ }^{67}$ This was a distinction that Leo did not observe prior to $45^{2}$, and reflects a new emphasis on the humanity of Christ as a corrective to the "high" Alexandrian Christology exemplified by Eutyches. As Green put it in a succinct formulation that underlines the significance of this letter, "The Christ whom Leo preached as the source of his mes-

63 Leo's Homilies 64 and 65 are really one long homily split into two and delivered three days apart, on Easter Sunday and the following Wednesday, so as not to fatigue the audience: serm. 64.4 (ed. Chavasse, vol. 2, p. 394).

$64 \quad$ Leo I, ep. 124, preface.

65 Barclift, "The Shifting Tones," p. 227, n.219.

66 James, "Leo the Great and Prosper of Aquitaine," pp. 557-558.

67 Barclift, "The Shifting Tones," pp. 230-239. 
sage of civic Christianity, the Mediator bringing humanity and divinity together in his person, creating a community of love for all people, was the Christ whose identity reached fullest expression in his letter to the Palestinian monks of $453 . " 68$

The conciliatory tone of Letter 124 is markedly different from that of Leo's letter of the preceding November to Julian of Cóos, ${ }^{69}$ where Leo denounces the same "false monks" for the riots that spread from Jerusalem to the whole of Palestine after the monk Theodosius returned from Chalcedon supporting one-nature Christology. These Palestinian monks had killed Severian, bishop of Scythopolis, and threatened to do the same to Juvenal, bishop of Jerusalem, who wisely fled into exile. Leo roundly condemned their violence and ignorance, likening them to soldiers of the Antichrist: "But these insolent disturbers [of the peace], who boast of their insults and injuries to priests, are to be considered not servants of Christ, but soldiers of the Antichrist, and must be chiefly brought low through their leaders, who incite the ignorant mob to defend their insubordination." ${ }^{70}$ This is a clear expression of what Weber called "hierocratic coercion".71 It is in the context of monastic unrest in the aftermath of Chalcedon that we can understand several other letters sent by Leo to the bishops of Antioch and Cyrrhus, in Syria. Writing to Maximus, bishop of Antioch, on 11 June 453 - around the same time as the composition of Letter 124 - Leo forbade preaching by monks and laymen, reserving this activity to priests and bishops. ${ }^{72}$ His letter to Theodoret of Cyrrhus, written on the same day, reiterated the injunction sent to Maximus. ${ }^{73}$ Letter 118 to Julian of Cóos also forbade monks to preach. ${ }^{74}$ Leo attempted to quash the charismatic authority of Eutyches' monastic support base by imposing institutional limitations on the office of preaching.

68 Green, Soteriology, p. 252. At pp. 230-247, Green gives a detailed analysis of the theological content of ep. 124.

69 Leo I, ep. 109, November 452. W.H.C. Frend, The Rise of the Monophysite Movement: Chapters in the History of the Church in the Fifth and Sixth Centuries, Cambridge, 1972, p. 147, identifies Cóos as Kios in Bithynia, following E. Caspar, Geschichte des Papsttums von den Anfängen bis zur Höhe der Weltherrschaft, vol. 1, Tübingen, 1933, p. 481.

$70 \quad$ Leo I, ep. 109.2 (ed. Schwartz, Aco, 2.2.1, p. 137; trans. Hunt, p. 206).

71 See note 11 above.

72 Leo I, ep. 119.6.

73 Leo I, ep. 120.6 .

74 D. Caner, Wandering, Begging Monks. Spiritual Authority and the Promotion of Monasticism in Late Antiquity, Berkeley-Los Angeles, 2002, pp. 239-240, discusses Leo's successful efforts to enlist Faustus and Martinus, both archimandrites of Constantinople and open opponents of Eutyches, as his agents in the imperial capital in $45^{\circ}$. 
Unfortunately, these letters did not prevent more violence in Egypt over the Alexandrian patriarch Proterius' adherence to the Tome. Proterius had been ordained in place of Dioscorus in $45^{2}$ after the latter's deposition at Chalcedon. In a letter of 454, Leo advised Proterius to clear himself of all charges of Nestorianism by reading out selections from certain Fathers and finally from Leo's Tome, "... so that the ears of the faithful may have proof that we preach nothing other than what we have received from our predecessors." ${ }^{.75}$ This appeal to traditional authority must have infuriated those who felt that Proterius had betrayed the memory of his predecessor Dioscorus by omitting his name from the diptychs, the list of persons of holy memory that was recited in the course of each liturgy. The anti-Chalcedonians had to bide their time until the death of Emperor Marcian in early 457, whereupon, under the leadership of Timothy Aelurus and his associate Peter Mongus, they besieged the patriarch in church. Proterius was put to the sword in a baptistery on Easter Day and his corpse dragged around the city streets on a rope before being dismembered and burnt. ${ }^{76}$ Timothy Aelurus was then illegitimately installed as patriarch. When Leo found out about it some months afterwards, he was furious and appalled, as Letter 149 indicates: "For the entire Christian religion -- and this must often be repeated -- is disturbed if any of the decisions made at Chalcedon is done away with."77 What had started out as a difference in attitudes to the importance of the humanity of Jesus vis à vis the divinity of Christ became a source of wide-scale social division and, in some regions, violent conflict.

In Leo the Great's dealings with the doctrinal conflict aired at Chalcedon, we find him employing multiple strategies of avoidance: he did not attend the council in person but sent emissaries; he alleged that miscommunications with various eastern bishops were the result of faulty Greek translations; he claimed a lack of consultation through letters crossing each other in the post. As a more positive strategy, he appealed to the traditional authorities, the church Fathers whose faith he claimed to uphold against heretics. When these strategies failed, he escalated the conflict by denouncing with anathema those

75 Leo I, ep. 129.2 (ed. Schwartz, ACO, 2.2.1, p. 85; trans. Hunt, p. 216).

${ }_{76}$ This is the account given by Evagrius, Historia ecclesiastica 2.8 (ed. A. Hübner, Evagrius Scholasticus, Historia ecclesiastica. Kirchengeschichte, 2 vols. [Fontes christiani, 57] Turnhout, 2007, pp. 238-240). Cf. Liberatus of Carthage's Breviarium 15, an alternative source on Proterius' death, cited by C.B. Horn, Asceticism and Christological Controversy in Fifthcentury Palestine. The Career of Peter the Iberian (Oxford Early Christian Studies), Oxford, 2006, pp. 95-96. According to Liberatus, Proterius died on Holy Thursday, 28 March 457, twelve days after Timothy Aelurus had been chosen as patriarch. Leo I, ep. 149 (ed. Schwartz, Aco, 2.4, p. 98; trans. Hunt, p. 238); see also epp. 150 and 165 to Emperor Leo. 
who enacted the "Robber Synod" of Ephesus. Further escalation was fuelled by his demands for a new "ecumenical" council, in the hope that the collegiality of bishops would moderate the monocratic tendencies of Emperor Theodosius II. Leo I attempted to resolve the conflict by lobbying those who enjoyed traditional and legal power, availing himself of the epistolary social networks that bound him to the imperial household, and patriarchs of the three most important sees, Alexandria, Antioch, and Constantinople. The conflict was enflamed by adherents of two rivals who exercised charismatic authority in the church: the bishop of Rome on the one hand, supported by the emperor Marcian and his family, and on the other hand the monks who had gathered to support Eutyches, archimandrite of Constantinople. When the conflict over a matter of Christological definition spread beyond the original three protagonists - Eutyches and Flavian of Constantinople, and Leo of Rome - the religious conflict caused widespread violence across the empire. In this way a local religious conflict became a social conflict whose implications continue to have an impact on attempts to unify the eastern and western Christian churches up to the current day.

\section{Case 3: The Disputed Papacy of Symmachus}

A good example of an ostensibly ecclesiastical conflict which masked underlying political divisions is the famous Laurentian schism, between supporters of Symmachus and his rival for the papal throne, Laurence, a priest of Rome. ${ }^{78}$ The increasing power of the bishop of Rome claimed by Leo I corresponded with stronger rivalry between candidates for the see after his pontificate. The election of the bishop by the acclamation of the clergy and the Roman people disguised a great deal of political machination behind the scenes, and the election of rival candidates was not uncommon. Any candidate's election required ratification by the traditional and legal authority of the emperors, based first in Rome, then until 476 in Milan, and thereafter solely in Constantinople.

When Pope Anastasius II died suddenly in 498 after only two years on the papal throne, rival factions in Rome scrambled to get the institutional authority they needed to support their own choices of candidate. There were two main contenders: the aristocrat Symmachus, who had senatorial support, and

78 The seminal study remains E. Wirbelauer, Zwei Päpste in Rom: Der Konflikt zwischen Laurentius und Symmachus (498-514), Munich, 1993. See also T. Sardella, Società Chiesa e Stato nell'età di Teoderico. Papa Simmaco e lo scisma laurenziano, Soveria Mannelli, 1996. Cf. Sessa, Formation of Papal Authority, 208-246, discussed below. 
Laurence, a Roman priest, who had the support of the Byzantine emperor Anastasius I and initially of the Ostrogothic ruler of Italy, Theodoric. Laurence was first of the two to be installed in the Lateran Palace, but his election was then challenged by Symmachus. Symmachus was then ordained bishop of Rome and Laurence was made bishop of Nuceria, but Symmachus's election was opposed by two ex-consuls, Festus and Probinus, who acted "out of jealousy," according to the anonymous author of the Liber Pontificalis. ${ }^{79}$ Four years later conflict again erupted on the streets of Rome with Laurence's attempt to reclaim the Roman see. Each contender appealed to Theodoric for support and both may have resorted to bribery. ${ }^{80}$ Fighting in the streets between pro-Symmachan and pro-Laurentian senatorial factions resulted in the deaths of clergy, monks, dedicated virgins, ${ }^{81}$ and even several noblemen. In a Decretal delivered by the Roman Synod of 499, over which he presided, Symmachus described the sequence of events thus: ${ }^{82}$

Then there was a riot as a crowd of rivals rushed in, and as with the many priests who had gone in with him, death occurred during that slaughter. The nobleman (illustris vir) Count Arigernus still bears traces of recent wounds, as do Gudila and Bedeulfus, both men of high rank in the royal house. We went again to the king and implored his justice. Theodoric recommended a synod be held to resolve the issue.

The Roman Synod of 499 decided in Symmachus's favour. Political strife here seems to have spilled over into ecclesiastical struggle and violence. Traditional interpretations have seen the senatorial factions as divided over their support for imperial control over Rome from Byzantium. ${ }^{83}$ Peter Llewellyn highlighted

79 L. Duchesne, C. Vogel (eds.), Le Liber Pontificalis, vol. 1, 2nd edn, Paris, 1955 [= LP], p. 257. On its unreliability as a historical source, see P. Blaudeau, "Narrating Papal Authority (440 -530): The Adaptation of Liber Pontificalis to the Apostolic See's Developing Claims," in: The Bishop of Rome, ed. Dunn, pp. 127-140.

80 J. Richards, The Popes and the Papacy in the Early Middle Ages 476-752, London, 1979, p. 70.

$81 \quad L P 1$, p. 257.

82 Decretum synodale, dated 1 March 499; ed. A. Thiel, Epistulae Romanorum Pontificum genuinae et quae ad eos scriptae sunt a s. Hilaro usque ad Pelagium II, Fasciculus I, 2nd edn, Braunsberg, 1867; repr. Hildesheim, 2004, p. 661, where Symmachus defended his election against the claim of Laurence.

83 E.g. J. Moorhead, "The Laurentian Schism: East and West in the Roman Church," Church History, 47/2 (1978), pp. 125-136. 
the rivalry between clerical offices, namely, between deacons and priests. ${ }^{84}$ Thomas Noble, on the other hand, saw as decisive Theodoric's intervention against those who supported eastern rule over Italy. ${ }^{85}$ More recently, Kristina Sessa has plausibly argued that the conflict had an economic motive: that Symmachus's unpopularity was due to questions about his stewardship over property of the church, and to his desire to control the finances of the titular, or privately endowed, churches in Rome, a considerable source of revenue. ${ }^{86}$ These widely varying interpretations, based on limited written sources which are full of discrepancies, if not diametrically opposed, show that motives for conflict can be multiple. This was also evident in the case of the Chalcedonian conflict over the natures of Christ. Symmachus's failure to engage different levels of support for his authority - senatorial as well as popular - ultimately led to the instability of his pontificate.

\section{Conclusion}

In seeking to trace the path of conflicts and their escalation or resolution, contemporary social conflict theorists look for incompatible goals, differentials in power, access to social resources, the exercise of control, the expression of dissent, and the strategies employed in responding to disagreements. We have seen that these tools of interpretation are just as applicable to the analysis of historical doctrinal conflicts in Late Antiquity as they are to understanding modern conflicts. These three brief case studies have shown different styles of papal leadership leading to very different outcomes, and the interplay of prestige, power and (in Case 3) property with theological issues to create social conflict. In Case 1, we saw that Zosimus adopted a legalistic approach to the role of pope as arbiter of disputes between high-ranking bishops of Gaul, one that ultimately failed to satisfy any of the parties involved. Case 2 considered Leo's successful interventions in eastern doctrinal disputes between 448 to 454

\footnotetext{
84 P.A.B. Llewellyn, "The Roman Clergy during the Laurentian Schism," Ancient Society, 8 (1977), pp. 245-275.

85 T.F.X. Noble, "Theoderic the Great and the Papacy," in: Teoderico il Grande e i Goti d'Italia. Atti del XIII Congresso internazionale di studi sull'Alto Medioevo, Milano, 2-6 novembre 1992, ed. O. Capitani, 2 vols Spoleto, 1993, pp. 395-423.

86 Sessa, Formation of Papal Authority, pp. 208-246. Demacopoulos, "Are All Universalist Politics Local?" pp. 102-116, gives a good summary of Sessa's and others' interpretations of the primary sources: Symmachus' Decretum Synodale, the forged Gesta Symmachi, the Laurentian Fragments, and the LP. See also Blaudeau, "Narrating Papal Authority," pp. 132133.
} 
through the writing of letters, including the (in)famous Tome to Flavian, Letter 124 to the rioting monks of Palestine, and Letter 165 addressed to Emperor Leo, the so-called Second Tome. As bishop of Rome, Leo appealed to his spiritual (charismatic) power as constituting a higher authority than the secular (legal, traditional) power held by the imperial couple. Luckily for Leo, with the change of imperial leadership from Theodosius to Marcian, the interests of both coincided. Perhaps the secret of Leo's success was his capacity to invoke all three kinds of authority: charismatic, legal, and traditional. In Case 3, we saw that the reasons for opposition to contested papal candidate Symmachus lay in economic factors as well as factional loyalties that divided the two main interest groups, the senators and plebs Romana.

All three ecclesiastical controversies discussed here had as much to do with differing claims to authority as with concerns over rules of appeal, episcopal hierarchies, episcopal elections or accurate Christological statements. The ensuing social conflicts had far-reaching and unforeseen consequences which entailed the persecution, often violent, of the non-orthodox, as well as violent resistance from the non-orthodox themselves. The fallout from Chalcedon continued into the sixth century with the dispute over the Three Chapters (543-53), whose implications for East-West church relations continued up to the papacy of Gregory the Great (590-604). For the so-called miaphysite ("one nature") Coptic church and the Church of the East, ${ }^{87}$ it resulted in a long-term estrangement from communion with Rome or the Orthodox patriarchate of Constantinople (Istanbul).

We have seen that the issues underlying these three fifth-century disputes in Rome and the wider church were never solely theological. The complex interrelations between the governing ideals and charismatic appeal of the various personae of the controversies also made life difficult for fifth-century Roman bishops like Zosimus, Leo I and Symmachus. Unlike the other two, Leo combined impressive social networks and a command of traditional sources of ideological authority with considerable charismatic appeal. This combination laid the foundations for the success - albeit limited - of his intervention in the Chalcedonian dispute.

87 The Church of the East separated into three branches: the Assyrian Church of the East, the Chaldeans, and the Ancient Church of the East. See N.N. Seleznyov, "Nestorius of Constantinople: Condemnation, Suppression, Veneration. With special reference to the role of his name in East-Syriac Christianity," Eastern Christian Studies 62-63 (2010), pp. 165-19o. 